(C) Nevoit G.V.

UDC 616-071:615.84

DOI https://doi.org/10.31718/mep.2020.24.5-6.05

\title{
POSSIBILITIES OF ELECTRO-PHOTONIC EMISSION ANALYSIS IN THE REPRESENTATION OF SYSTEM INFORMATION ENERGY PROCESSES OF THE HUMAN ORGANISM
}

Nevoit G.V.

Ukrainian Medical Stomatological Academy, Poltava, Ukraine

This research work is a fragment of the initiative research project "Development of algorithms and technology for introducing a healthy lifestyle in patients with non-communicable diseases based on the study of psycho-emotional status" (State registration No. 0116U007798, UDC 613:616-052:159.942:616-03).

y статті представлені результати визначення клініко-діагностичного потенціалу використання аналізу електрофотонічного викиду з пальців людини під час об'єктивного структурованого клінічного обстеження. Мета дослідження - оцінка клінічних та діагностичних можливостей аналізу електрофотонної емісії у відображенні системних інформаційних енергетичних процесів людського організму для підвищення ефективності заходів щодо запобігання та лікування НІЗ шляхом поліпшення діагностики та профілактики шляхом впровадження сучасних наукомістких технологій та розробки магнітоелектрохімічної концепції обміну речовин. Представлені результати відкритого, нерандомізованого, контрольованого дослідження 56 функціонально здорових респондентів, які систематично не займаються спортом. Аналіз електрофотонної емісії був виконаний на сертифікованому вимірювальному приладі - камері Біовел ГРВ 2.0 (Віо-Well, Росія-США). В результаті дослідження встановлено різні рівні функціонального стану та різний ступінь здоров'я у респондентів. Метод аналізу електрофотонної емісії дозволяє на основі обробки даних стосовно інтенсивності та характеру локалізації емісії фотонів з пальців рук респондента розрахувати параметри стану метаболізму речовин на тканинному рівні та опосередковано оцінити загальний функціональний стан пацієнтів. Аналіз аналізу електрофотонної емісії пропонується авторами для можливого використання в клінічній медицині з метою об'єктвної оцінки енергетичного статусу пацієнта.

Ключові слова: неінфекційні захворювання, об'єктивне клінічне обстеження, аналіз електрофотонної емісії.

The article presents the results of determining the clinical and diagnostic potential of using the electro-photonic emission analysis from human fingers during an objective structured clinical examination. The aim of the study is to assess the clinical and diagnostic capabilities of electro-photonic emission analysis in the reflection of systemic information energy processes of the human body to increase the effectiveness of measures to prevent and treat NCDs by improving their diagnosis and prevention through the introduction of modern science-intensive technologies and scientific magnetoelectrochemical concept of metabolism. The results of the open, non-randomized, controlled study of 56 functional respondents who do not systematically engage in sports are presented. The electro-photonic emission analysis was performed on a certified measuring device Bio-Well GDV Camera 2.0 (Bio-Well, Russia-USA). Different levels of functional status and different degrees of health were established as a result of the study. The method of electrophoton emission analysis allows us to calculate the parameters of the state of metabolism of substances at the tissue level and indirectly assess the general functional state of patients based on data processing regarding the intensity and nature of localization of photon emission from the fingers of the respondent. The method for the electro-photonic emission analysis is recommended by the authors for possible use in clinical medicine in order to objectively assess the energy status of the patient.

Key words: non-communicable diseases, objective structured clinical examination, electro-photonic emission analysis.

\section{Introduction}

Non-communicable diseases (NCDs) are a significant world-class medical and social problem. NCDs cause deaths of 41 million people each year. NCDs lead to disability and mortality of about 15 million people of working age each year. NCDs is a background pathology for a significant number of patients. NCDs worsen their quality of life and the course of comorbid diseases. NCDs worsen the course of COVID-19 coronavirus infection as well. These facts determine the urgency of further search for new approaches and ideas to solve the problem of NCDs [1].

Scientific and technological progress of fundamental scientific fields has deepened the understanding of the structure and electromagnetic properties of matter of animate and inanimate nature. It is established that all matter has an electromagnetic structure. Modern ideas about the structure of the atom are based on the standard model of fundamental interaction and quantum field theory. The atom has both corpuscle and field properties (corpuscular-wave dualism) and it consists at the subatomic level of diametrically opposed supersymmetric complementary field structures/fermions. Fermions are connected by field connections/bosons according to modern fundamental knowledge. The principles of the structure of atoms are universal for all living and inanimate matter of the Universe. Thus, modern fundamental knowledge about the electromagnetic organization of matter determines the possibility of a fundamentally different interpretation of the human body. The human body

${ }^{*}$ To cite this English version: Nevoit G.V. Possibilities of electro-photonic emission analysis in the representation of system information energy processes of the human organism. // The Medical and ecological problems. - 2020. - Vol 24, № 5-6. - P. 17-20 
can now be described as a complex of field structures of different tissues and organs with individual frequency characteristics/physical fields (infrared, optical, magnetic, electromagnetic, acoustic, electrostatic) as well. Physical electromagnetic fields of the human body are generated in the process of life and they are an adequate reflection of the biophysical reality of the phenomenon of life. The wave electromagnetic characteristics of the atom are the primary information carrier. It is the electromagnetic characteristics of atoms that determine its properties and the properties and manifestations of the material objects of animate and inanimate nature formed by them. The human body is an atomic conglomerate as well. The human body is formed according to the universal laws of fundamental atomic / nuclear interaction as well. Electromagnetic wave manifestations of the human body are combinations of electromagnetic characteristics of all its atoms of different hierarchical levels of interaction, respectively. We continue to study this cluster of scientific knowledge from the standpoint of systems medicine. This cluster of research is promising, as the new knowledge gained can help generate other innovative approaches to solving the problem of NCDs by developing the views of the magnetoelectrochemical concept of metabolism, which we propose [1].

Human skin is a complex formation with heterogeneous electrical properties. The skin is involved in metabolism and it has an energy-information connection with the internal organs and the external environment. The fingers of the extremities are fractal parts of the human body and the study of the electromagnetic properties of their skin continues to be of fundamental scientific interest. The electro-photonic emission analysis (EPEA) from human fingers is proposed by us as one of the promising methods of studying the systemic electromagnetic energy processes of the human body in an objective structured clinical examination of the patient [2].

The aim of the study is to assess the clinical and diagnostic capabilities of EPEA in the reflection of systemic information energy processes of the human body to increase the effectiveness of measures to prevent and treat NCDs by improving their diagnosis and prevention through the introduction of modern science-intensive technologies and scientific magnetoelectrochemical concept of metabolism.

\section{Materials and methods}

Open, non-randomized, controlled study was performed on the basis of the educational and practical center of biophotonics and valeology of the Department of Internal Medicine and Emergency Medicine of the Educational and Scientific Institute of Postgraduate Education at Ukrainian Medical Stomatological Academy (UMSA) and physiotherapy department of the municipal enterprise "M.V. Sklifosovsky Regional Clinical Hospital of the Poltava regional council". The EPEA study of the control group of functionally healthy respondents was a fragment of it. Full EPEA with 10 fingertips was done three times (in the background, after orthostatic test, after dynamic test - 7 squattings) 56 functionally healthy respondents (students, interns, clinical residents of UMSA) who do not engage in sports activities regularly; (median age - 23 $(19 ; 35)$ years, men - $18(32 \%)$.
The EPEA was performed on a Bio-Well GDV Camera 2.0 (Bio-Well, Russia-USA). This instrument is being used in a wide range of scientific and practical applications in 70 countries. Bio-Well camera has CE, EU and FDA certifications. This method, promising for medicine, was based on the physical phenomenon of the electrophotonic emission - flow of electrons from a conductive object under the influence of high frequency high intensity electro-magnetic impulse that creates photonic emission (Glow) in the air gas discharge visualization (GDV). The modern digital software package Electro-Photonic Imaging (EPI) was used as the basis for recording the parameters of the phenomenon of electro-photonic emission from human fingers in the Bio-Well GDV Camera 2.0 device and analyzing the results. The EPI is based on computer image analysis of photons, emitted by a subject in strong impulse electromagnetic field. We used the Full scan mode in our study. Full Scan was regime of capturing $\mathrm{Gl}$ of human fingers (all ten) in the Bio-Well Software that allows to get maximum parameters about functional (energetic) state of a person, his/her systems and organs, based on intersection of each finger into sectors according to acupuncture points concept and more than 20 years of clinical studies. Direct and calculated parameters were evaluated by us: the Area (S, number of pixels of the Glow Image ( $\mathrm{Gl}$ ); it is ratio of area of the finger emission to the glow area of calibration cylinder (for sector or whole image); the Normalized Area is the ratio of $\mathrm{Gl}$ area to the area of the inner oval; the Intensity is average intensity of all the pixels from the Gl; the Energy of Glow (E, Joules/J; it is an integral indicator of functional state; it is a numerical estimate of the energy from the photographed emission of photons multiplied by the area, intensity and the correction factor); the Stress (c.u.; it is an integral parameter of the functional state of a person, it is a numerical assessment of the psychoemotional and functional state of the examined person, based on the assessment of the curvature of the outer contour of the photon emission of the fingers); the Form Coefficient (FC; it is calculated according to the formula: $F C=L 2 / S$, where $L$ is the length of the $G$ l external contour and $S$ is the GI Area; it reflects the degree of roughness of the outer contour of the photon emission image. it is assessed for each finger of the hand, for fingers on both hands and separately for the right and left hands in average parameters;); the Entropy Coefficient (EC; it is the ratio of outer contour to the inner contour lengths); the Balance (B, \%), Balance left (BL, \%) and Balance right $(\mathrm{BR}, \%)$ reflect the presence or absence of asymmetry (the phenomenon of lateralization); the Energy Field (EF) is an abstract parameter, it is the result of a computer simulation of emission from ten fingers; left and right Energy Field Energy $\left(\mathrm{E}_{\mathrm{EF}} \mathrm{L}, \mathrm{E}_{\mathrm{EF}} \mathrm{R}, \mathrm{J}\right)$; left and right Energy Field Area $\left(\mathrm{S}_{\mathrm{EF}} \mathrm{R}, \mathrm{S}_{\mathrm{EF}} \mathrm{R}, \mathrm{c}\right.$.u. $)[1,3-5]$.

Statistical analysis was performed using the Prism 5.0 software package. The data obtained are presented as mean values with their mean error $(M \pm m)$. Wilcoxon matched-pairs signed rank test were used to determine the statistical significance of differences between groups. Differences were considered significant at $p<0.05$.

\section{Results and discussion}

The results of the survey of the group are shown in Table 1. 
Проблеми екології та медицини

Comparative characteristics of the parameters of the EPEA

\begin{tabular}{|c|c|c|c|c|c|}
\hline \multirow[b]{2}{*}{ Indicator } & \multirow{2}{*}{$\begin{array}{c}\text { background state } \\
\text { Data } 1\end{array}$} & \multicolumn{2}{|c|}{ orthostatic test } & \multicolumn{2}{|c|}{ dynamic test } \\
\hline & & Data 2 & $\begin{array}{l}\text { two-tailed } \\
\text { P value; } \\
\text { one-tailed } \\
\text { P value }\end{array}$ & Data 3 & $\begin{array}{l}\text { two-tailed } P \text { value; } \\
\text { one-tailed } P \text { value }\end{array}$ \\
\hline Stress, c.u. & $3.68 \pm 0.70$ & $3.63 \pm 0.86$ & $\begin{aligned} P_{1-2} & =0.36 \\
P_{1-2} & =0.0007\end{aligned}$ & $3.55 \pm 0.55$ & $\begin{array}{c}P_{1-3}=0.13, P_{2-3}=0.93 \\
P_{1-3}<0.0001, P_{2-3}<0.0001\end{array}$ \\
\hline$E^{*} 10^{-2}, J$ & $52.49 \pm 3.57$ & $53.41 \pm 3.51$ & $\begin{array}{l}P_{1-2}<0.001 \\
P_{1-2}<0.0001\end{array}$ & $53.42 \pm 3.45$ & $\begin{array}{c}P_{1-3}=0.001, P_{2-3}=0.83 \\
P_{1-3}<0.0001, P_{2-3}<0.0001\end{array}$ \\
\hline$B, \%$ & $97.15 \pm 2.02$ & $97.08 \pm 2.23$ & $\begin{array}{l}\mathrm{P}_{1-2}=0.73 \\
\mathrm{P}_{1-2}=0.341\end{array}$ & $97.27 \pm 2.17$ & $\begin{array}{l}P_{1-3}=0.7, P_{2-3}=0.68 \\
P_{1-3}=0.06, P_{2-3}=0.44\end{array}$ \\
\hline $\mathrm{BL}, \%$ & $91.74 \pm 6.32$ & $92.92 \pm 5.94$ & $\begin{array}{l}\mathrm{P}_{1-2}=0.09 \\
\mathrm{P}_{1-2}=0.006\end{array}$ & $92.72 \pm 5.53$ & $\begin{array}{l}P_{1-3}=0.18, P_{2-3}=0.76 ; \\
P_{1-3}=0.12, P_{2-3}=0.21\end{array}$ \\
\hline $\mathrm{BR}, \%$ & $91.91 \pm 6$ & $93.89 \pm 5.08$ & $\begin{array}{l}\mathrm{P}_{1-2}=0.17 \\
\mathrm{P}_{1-2}=0.07\end{array}$ & $93.68 \pm 4.83$ & $\begin{array}{l}P_{1-3}=0.09, P_{2-3}=0.98 \\
P_{1-3}=0.17, P_{2-3}=0.31\end{array}$ \\
\hline FC & $2.72 \pm 0.26$ & $2.76 \pm 0.23$ & $\begin{array}{c}\mathrm{P}_{1-2}=0.23 \\
\mathrm{P}_{1-2}<0.0001\end{array}$ & $2.76 \pm 0.22$ & $\begin{array}{c}P_{1-3}=0.19, P_{2-3}=0.55 \\
P_{1-3}<0.0001, P_{2-3}<0.0001\end{array}$ \\
\hline EC & $2.46 \pm 0.26$ & $2.52 \pm 0.24$ & $\begin{array}{c}P_{1-2}=0.01 \\
P_{1-2}<0.0001\end{array}$ & $2.53 \pm 0.23$ & $\begin{array}{c}P_{1-3}=0.01, P_{2-3}=0.44 \\
P_{1-3}<0.0001, P_{2-3}<0.0001\end{array}$ \\
\hline$S_{E F} L$, c.u. & $71887 \pm 6356$ & $73784 \pm 5737$ & $\begin{array}{c}\mathrm{P}_{1-2}<0.0001 ; \mathrm{P}_{1-} \\
{ }_{2}<0.0001\end{array}$ & $74021 \pm 5582$ & $\begin{aligned} \mathrm{P}_{1-3} & =0.0003, \mathrm{P}_{2-3}=0.62 ; \\
\mathrm{P}_{1-3} & <0.0001, \mathrm{P}_{2-3}<0.0001\end{aligned}$ \\
\hline$E_{E F} L, J$ & $33.57 \pm 4.12$ & $33.8 \pm 3.72$ & $\begin{array}{l}P_{1-2}=0.0002 \\
P_{1-2}<0.0001\end{array}$ & $34.01 \pm 3,6$ & $\begin{array}{c}\mathrm{P}_{1-3}=0.0001, \mathrm{P}_{2-3}=0.38 \\
\mathrm{P}_{1-3}<0.0001, \mathrm{P}_{2-3}<0.0001\end{array}$ \\
\hline $\mathrm{S}_{\mathrm{EF}} \mathrm{F}, \mathrm{c} . \mathrm{u}$ & $70100 \pm 5564$ & $71675 \pm 5534$ & $\begin{array}{c}\mathrm{P}_{1-2}<0.0001 ; \mathrm{P}_{1}<0.0001 \\
{ }_{2}<\end{array}$ & $72101 \pm 52100$ & $\begin{array}{c}\mathrm{P}_{1-3}=0.0001, \mathrm{P}_{2-3}=0.31 ; \\
\mathrm{P}_{1-3}<0.0001, \mathrm{P}_{2-3}<0.0001\end{array}$ \\
\hline$E_{E F} F, J$ & $31.69 \pm 3.66$ & $32.83 \pm 3.71$ & $\begin{array}{c}\mathrm{P}_{1-2}<0.0001 ; \mathrm{P}_{1-} \\
{ }_{2}<0.0001\end{array}$ & $33.06 \pm 3.46$ & $\begin{array}{c}\mathrm{P}_{1-3}=0.0001, \mathrm{P}_{2-3}=0.38 \\
\mathrm{P}_{1-3}<0.0001, \mathrm{P}_{2-3}<0.0001\end{array}$ \\
\hline$S_{E F} R$, c.u. & $72189 \pm 6176$ & $73759 \pm 5900$ & $\begin{array}{l}P_{1-2}=0.0005 \\
P_{1-2}<0.0001\end{array}$ & $74064 \pm 5161$ & $\begin{aligned} \mathrm{P}_{1-3} & =0.0003, \mathrm{P}_{2-3}=0.55 \\
\mathrm{P}_{1-3} & <0.0001, \mathrm{P}_{2-3}<0.0001\end{aligned}$ \\
\hline $\mathrm{E}_{\mathrm{EF}} \mathrm{R}, \mathrm{J}$ & $32.72 \pm 3.89$ & $33.74 \pm 3.85$ & $\begin{array}{l}P_{1-2}=0.0092 \\
P_{1-2}<0.0001\end{array}$ & $33.91 \pm 3.41$ & $\begin{aligned} \mathrm{P}_{1-3} & =0.0002, \mathrm{P}_{2-3}=0.69 ; \\
\mathrm{P}_{1-3} & <0.0001, \mathrm{P}_{2-3}<0.0001\end{aligned}$ \\
\hline
\end{tabular}

The group analysis showed that the energetic functional state of the group respondents was within the normal range. The group has a relatively average optimal energy level. This may be due to the lack of regular physical activity and physical inactivity. The stress level is set above normal in the group, and it corresponds to the level of anxiety. Balance and energy field readings are normal in group data analysis. The results obtained refer the respondents to the second health group according to the works of the authors of the methodology.

The practical value of the EPEA method consists in the ability to diagnose the preclinical stage of NCDs by assessing the level of health, functional status and energy reserve. The authors of the methodology have developed a practical classification of health groups: the first group includes absolutely healthy respondents with a high quality of psychosomatic health; the second group includes functionally healthy respondents with functional changes in psychosomatic status and stigmas of a premorbid state; the third group includes respondents with existing risk factors for NCDs and chronic diseases of internal organs in remission. The respondents we surveyed are not completely healthy and can be attributed to the second or third health group according to the analysis of personal EPEA indicators. The optimal stress level was diagnosed in $8(14 \%)$, anxiety was diagnosed in $32(57 \%)$, the average stress level was diagnosed in $15(27 \%)$ respondents. Clinical interpretation is recommended as follows: 0-2 c.u. - calm state; 2-3 - optimal condition; 3-4 c.u. - anxiety; 4-6 c.u. - average condition; 6-8 c.u. - increased stress levels; 8-10 - distress.

Energy level is a key integral indicator of the EPEA method. The uniqueness and clinical value of the EPEA method lies in the ability to objectively assess energy processes at the tissue level. Systemic energy processes occur in living biological tissues due to the intermolecular transport of excited electrons and the migration of electrical excitation energy without detachment from the donor molecule. The biomolecule converts the nonspecific chemical energy of adenosine triphosphate into molecule-specific energy quanta/solitons. Solitons combine into two streams in the processes of functioning of living matter. All energy consumed by the body is included in a powerful "biochemical" flow/"quantum packets". It moves mainly along biopolymer chains, and it maintains their structure, mechanical conformations and chemical interactions. The second stream is a significantly weaker "control" stream ("one-quantum processes"). The quanta of this flux interact resonantly with the molecules. The "control" flow combines biopolymers with their aqueous environment into a single multimolecular complex. All biopolymers of the body are elements of a single organismic system, which is in a self-consistent state due to this. Living molecules and human tissues emit photons during metabolism. This phenomenon was discovered in the XXI century, and it was named ultra-weak photon emission (UPE). Today, the spectrum and intensity of a person's UPE is considered recognized, and the main source, statistical distribution, fractality is partially understood. Ultrasensitive digital equipment is required for UPE registration and this limits its use in clinical medicine. The EPEA method is widely available in medicine, and it displays similar energy tissue processes with electrical stimulation of photon emission from human tissue. The physical essence of the EPEA method is based on the occurrence of an electric discharge when short (3-5 
$\mu s)$ pulses of an electromagnetic field are applied. This leads to the ionization of the molecules of the gaseous medium due to the emitted electrons and photons, the charging of the surface, and this causes the transport of electrons from the surface of the human fingers along the structural complexes of biomolecules into the chain of flow of pulsed electricity. The phenomenon of electrophotonic emission is visible and is recorded by a digital camera for further analysis. Thus, the EPEA method allows us to determine indirectly the energy state of the molecular level of functioning of the structures of proteinlipid complexes. Clinical interpretation of the energy level is recommended as follows: $0-20 \mathrm{~J}$ - low level, $20-40 \mathrm{~J}$ low level, 40-70 J - optimal, 70-90 J - high level, 90-100 J high level. The state of absolute health is characterized by relatively high levels of energy. $15(27 \%)$ surveyed respondents had relatively low indicators of the optimal level $-<50 \mathrm{~J}$. At the same time, the median energy was 52.89(44.18; 59.64) J. This indicates that the energy processes at the tissue level in the respondents are less intense due to the lack of regular physical activity and physical inactivity.

Energy balance readings are important for clinical interpretation. Clinical interpretation of the energy balance between the left and right photon emission rates is recommended as follows: $0-50 \%$ - very low balance; $50-90 \%$ - low balance; $90-100 \%$ is the optimal balance. In clinical interpretation of the imbalance between the total energy of the luminescence of organs and systems (represented on both hands), expressed as a\% deviation from their mean value, the following is recommended: $0-5 \%$ - the optimal balance between the left and right sides; 5-10\% medium imbalance - a temporary adaptive response of the body to internal or external processes; $10 \%->15 \%$ severe imbalance - adaptation to extreme influences. The detection of the lateralization syndrome (the phenomenon of significant energy asymmetry) corresponds to disorders of the autonomic nervous system (autonomic lability) and this is an objective sign of a decrease in adaptation reserves and a violation of energy homeokinesis. The phenomena of local energy attenuation are also taken into account. The optimal level of balance was noted for all respondents. This is due to the presence of significant reserves in the young organism. However, 14 (25\%) people had normal balance of organs on the left and right. Lateralization syndrome was detected in 42 $(75 \%)$ respondents. This indicated that they had disorders of the autonomic nervous system and that they did not have a state of absolute health [3-5].
The deviations in the functional status of the respondents identified by the EPEA method were confirmed by the results of valeological testing, monitoring of body composition, and a study of the state of the autonomic nervous system using a short recording of heart rate variability. All of these studies identified functional inconsistencies and risk factors for NCDs in the respective respondents.

The dependence of the energetic functional status of the respondents on physical activity was established in the study. Indicators in dynamics after orthostatic and dynamic tests were significantly different (Table 1).

\section{Conclusions}

The EPEA method made it possible to objectively assess the systemic informational energy processes in functionally healthy young respondents who do not regularly engage in sports activities and to reveal the stigma of non-compliance of the functional state with the criteria of absolute health.

The EPEA method is a modern high-tech available valid instrumental technique for an objective assessment of systemic information energy processes of the tissue level of metabolism and the body as a whole.

EPEA can be recommended for clinical use in objective structured clinical examination.

Asthenovegetative syndrome remains the only clinical symptom complex without objective validation. Therefore, the study of the parameters of the functional state in this category by the EPEA method is of scientific interest and is a prospect for further research.

There is no conflict of interest.

\section{References}

1. Mintser O.P, Potiazhenko M.M., Nevoit G.V. Evaluation of the human bioelectromagnetic field in medicine: the development of methodology and prospects are at the present scientific stage. Wiadomości Lekarskie, 2019;5, II: 1117-1121. doi: 10.36740/WLek202006139

2. Bio-Well Manual. 2019. [Internet]. Available from: https://www.iumab.org/2019-bio-well-user-manual/

3. Korotkov K. Energy Fields Electrophotonic Analysis in Humans and Nature: Energy Fields Analysis. San Petersburg; 2014, 237 p.

4. Korotkov K. Review of EPI papers on medicine and psychophysiology published in 2008-2018. Int JComplement Alt Med., 2018;11(5):311-315. (in Englis

5. Korotkov K.G. Principles of the human body functioning and their applications in integrative medicine (review). J Appl Biotechnol Bioeng., 2018;5(6):346-348. (doi:10.15406/jabb.2018.05.00163

Матеріал надійшов до редакції 15.10.2020 